Boletín de la Sociedad Geológica Mexicana

VOLUMEN 66, NÚM. 3, 2014, P. 459-469

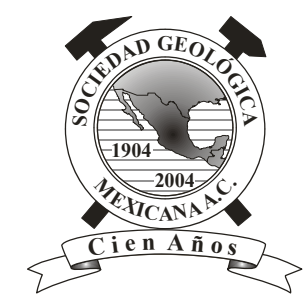

\title{
Freshwater mollusks of the Valley of Sobaco, Coahuila, Northeastern Mexico - a subfossil ecosystem similar to Cuatrociénegas
}

\author{
Alexander Czaja ${ }^{1, *}$, José Luís Estrada-Rodríguez ${ }^{1}$, Ulises Romero Méndez ${ }^{1}$ \\ ${ }^{1}$ Department of Biological Sciences, Juárez University of the State of Durango, 35010 Gómez Palacio, Durango, México. \\ *aaczaja@hotmail.com
}

\begin{abstract}
In the Valley of Sobaco located in Coahuila, Mexico, were found the remains of an aquatic ecosystem with a Holocene malacofauna showing similarities to modern aquatic communities of the internationally famous site of Cuatrociénegas, located in the state of Coahuila and known as the "Mexican Galapagos", as it hosts a large number of endemic species. In addition of ostracods, algae, foraminifera, diatoms and remains of vascular plants, the Sobaco paleo-pools (pozas) also contain the gastropods Juturnia coahuilae, Pyrgulopsis manantiali, Coahuilix hubbsi, Coahuilix cf. landyei and Assiminea cienegensis, which are endemic species of Cuatrociénegas Valley. Additional discoveries include sub-recent lacustrine microbial tufas (microbialites, stromatolites), as well a pool that still contains water hosting bacterial communities similar to those from Cuatrociénegas.

In this paper we present the taxonomic description of the mollusks from the Sobaco paleo-lake system and a first reconstruction of the paleoenvironment. A comparison of this paleoecosystem with modern aquatic communities of the Cuatrociénegas Valley is also included.
\end{abstract}

Keywords: Sobaco Valley, Cuatrociénegas Valley, lacustrine ecosystems, Holocene.

\section{Resumen}

En el Valle de Sobaco localizado en Coahuila, México, se encontraron restos de un ecosistema acuático con una malacofauna holocena que muestra grandes similitudes con las recientes comunidades acuáticas del internacionalmente famoso sitio Cuatrociénegas en Coahuila, llamado frecuentemente el "Galápagos Mexicano" debido a su gran número de especies endémicas. Además de varias especies de ostrácodos, algas, foraminíferos, diatomeas y restos de plantas vasculares en la paleo-poza de Sobaco, fueron encontrados los gasterópodos Juturnia coahuilae, Pyrgulopsis manantiali, Coahuilix hubbsi, Coahuilix cf. landyei y Assiminea cienegensis que hasta la fecha son conocidas como especies endémicas solo del Valle de Cuatrociénegas. Además fue espectacular el descubrimiento de tufas lacustres microbianas (microbialitos, estromatolitos), asi como de una poza con agua que contiene comunidades bacterianas recientes parecidas a las de Cuatrociénegas.

En este artículo presentamos la descripción taxonómica de los moluscos, una primera reconstrucción del paleo-ambiente así como una comparación de estos paleo-ecosistemas con las comunidades acuáticas recientes del Valle de Cuatrociénegas.

Palabras clave: Valle Sobaco, Valle Cuatrociénegas, ecosistemas lacustres, Holoceno. 


\section{Introduction}

The Valley of Sobaco is located southeast of the Chihuahuan Desert in the state of Coahuila, about $70 \mathrm{~km}$ southwest of Cuatrociénegas Valley (Fig. 1). The geological situation of Sobaco is very similar to that of Cuatrociénegas. Both valleys are enclosed by high mountain ranges composed of Cretaceous limestone (Acatita and Treviño Formations) intercalated with evaporitic units (gypsum). Both Quaternary valley fills are composed mainly of lacustrine sediments with a high content in carbonate and gypsum (SGM, 2003).

In 2013, a system of Holocene paleo-pozas containing travertine sands at Sobaco was discovered by the authors (Fig. 2). The paleo-poza Caracol, the largest of these sites, contains abundant gastropods, algae, ostracods, foraminifera, diatoms and remains of riparian vegetation. The stratigraphic position and lithological characteristics suggest that these alluvial sediments represent a Holocene surface sedimentary fill. Geological studies carried out by the Servicio Geológico Mexicano (Mexican Geological Survey) in the Valley of Sobaco also suggested a Holocene age for these lacustrine sediments (SGM, 2003).
The excellent state of preservation of the Sobaco shells, very different to the Late Pleistocene material of the region, also suggests a Holocene age.

Another water spring known from Sobaco is the poza Salada, technically a sinkhole, which holds bacterial communities resembling those of Cuatrociénegas (Fig. 3). These microbial mats of the Poza Salada are presently under investigation by Dr. Valeria Souza Saldivar from the Universidad Nacional Autónoma de México (UNAM) and by Dr. Jorge Saenz Mata from Universidad de Juárez del Estado de Durango (UJED).

The main objective of this paper is the determination and taxonomic description of the gastropods of the Sobaco paleo-pozas and to present a first reconstruction of the paleoenvironment, comparing this paleoecosystem with recent aquatic communities of the Cuatrociénegas Valley.

\section{Material and methods}

Seven samples of unconsolidated sediments were taken from a geological profile of the paleo-poza Caracol for taxonomic determination of its biota (Fig. 2 and 4;

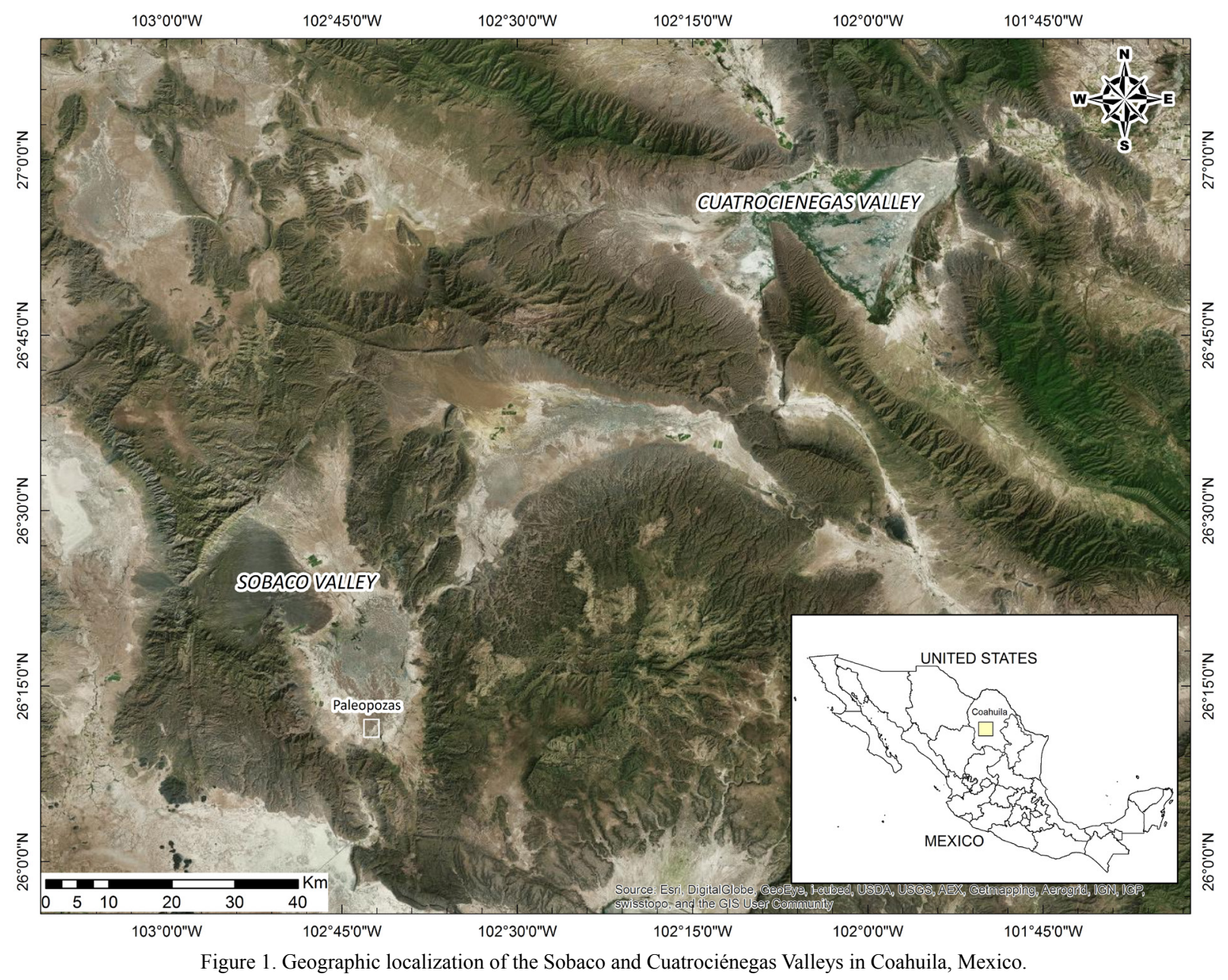




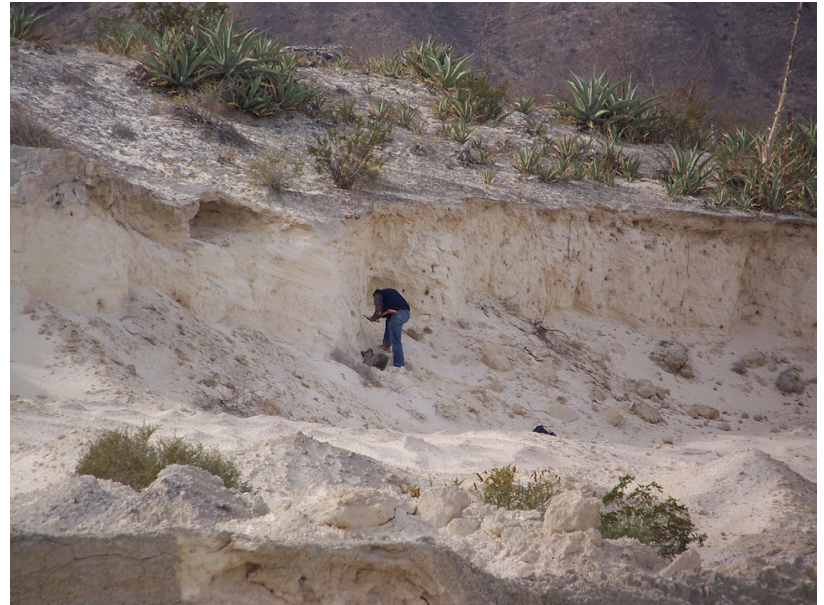

Figure 2. Geological profile of the paleo-poza Caracol with travertine sands, Sobaco Valley, Coahuila, Mexico.

$\left.26^{\circ} 10^{\prime} 43.2^{\prime \prime} \mathrm{N}, 102^{\circ} 42^{\prime} 40.0^{\prime \prime} \mathrm{W}\right)$. Two additional samples were taken from the outflows (arroyos) approximately 100 $\mathrm{m} \mathrm{SW}$ of the section $\left(26^{\circ} 10^{\prime} 20.9^{\prime \prime} \mathrm{N}, 102^{\circ} 42^{\prime} 59.0^{\prime \prime} \mathrm{W}\right)$. Sediments are unconsolidated and were screened through $0.5 \mathrm{~mm}$ and $0.3 \mathrm{~mm}$ sieves. The fossils were documented with a Zeiss AxioCam ERc5s microscope-camera.

The collected material is housed at the Faculty of Biological Science of the Universidad de Juárez del Estado de Durango (UJED), campus Gómez Palacio, Mexico.

The mollusks, foraminifera, ostracods and diatoms were identified by the authors, some of the gastropods (genus Assiminea) with the assistance of Dr. Robert Hershler, Smithsonian Institution, Washington. Dr. Amy Wethington, Chowan University, Norfolk, and Dr. Robert T. Dillon, Jr., Charleston, helped with the determination of the morphologically diverse genus Physa and Ferrissia.

\section{Systematic descriptions}

Family Cochliopidae Tryon, 1866

Genus Juturnia Hershler, Liu, and Stockwell, 2002

Juturnia coahuilae (Taylor, 1966) Hershler, Liu and Stockwell

(Fig. 5a-d)

Description: Shell ovate-conic to turriform, length: 2.2 $-5.2 \mathrm{~mm}$ (average $3-4 \mathrm{~mm}$ ), beige or clear, transparent. Teleoconch of $4.0-8.5$ slightly to strongly convex whorls. Surface corrugated to smooth, unsculptured, with fines growth lines. Sutures deeply impressed. Aperture ovate and small, inner lip thin to slightly thickened and usually narrowly adnate to parietal wall. Outer lip thin or slightly thickened.

Remarks: The most abundant species of the paleo-pozas of Sobaco Valley, with countless specimens, was determined

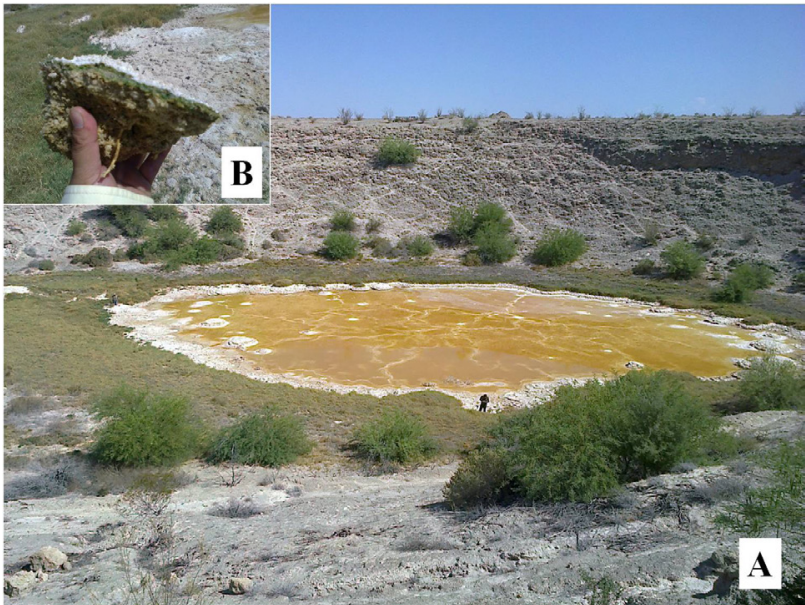

Figure 3. A: Poza Salada, Valley of Sobaco, Coahuila, Mexico. B: Microbial mats (microbialites) with a green layer of cyanobacteria.

as Juturnia coahuilae (Taylor) Hershler, Liu and Stockwell. The species is endemic to the Cuatrociénegas Valley and the fossil material from Sobaco corresponds in all details to the recent species regarding the morphology of the shell. The genus Juturnia includes Juturnia coahuilae, Juturnia kosteri and Juturnia tularosae, two species described from the Rio Grande region of New Mexico, U.S.A. According to Hershler et al. (2002), all three species of Juturnia are associated with saline environment. This interpretation agrees well with the ecological requirements of other species found at Sobaco.

Material: UJED-MAL-SOB-100, 101, 102A, approximately 800 specimens.

Genus Pyrgulopsis Call and Pilsbry, 1886

$$
\text { Pyrgulopsis manantiali (Hershler, 1985) }
$$

(Fig. 5e-g)

Description: Shell broadly conical, height: $0.95-$ $1.20 \mathrm{~mm}$, with 3 rounded whorls and an open umbilicus. Teleoconch whorls convex, with growth lines. Aperture broadly ovate to almost round, very slightly angled above, narrowly adhered or separated from the body whorl; inner lip complete, outer lip slightly thickened. Periostracum beige-colored.

Remarks: The genus Pyrgulopsis Call and Pilsbry includes more than 127 species in North America (Hershler and Liu, 2009). The material of Sobaco Valley corresponds to Pyrgulopsis manantiali (Hershler), a species endemic to the Cuatrociénegas Valley. According to Hershler (1994), Pyrgulopsis manantiali is distinct from all other species of the genus by its minute size and globose shells.

Material: UJED-MAL-SOB-103, 104, 105A, 150 specimens. 


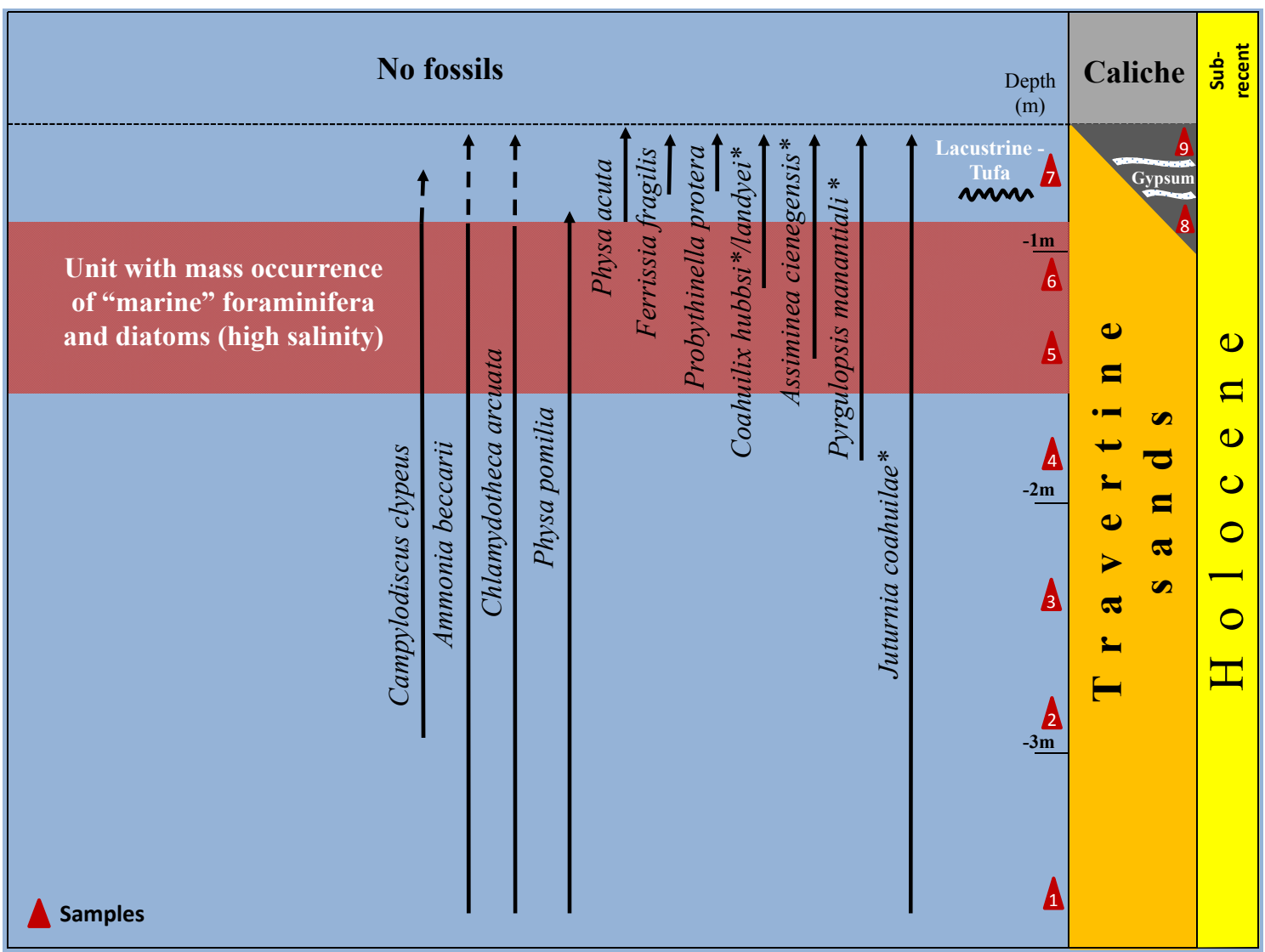

Figure 4. Generalized sediment sequence at paleo-poza Caracol, Sobaco Valley, Coahuila, Mexico. *=endemic species of gastropods in Cuatrociénegas. 1-7 = Samples from Paleo-Poza Caracol sequence, 8-9 = Samples from "Arroyo" (outflow).

Genus Coahuilix Taylor, 1966

Coahuilix hubbsi Taylor, 1966

(Fig. 5h, i)

Description: Shell minute, $0.95-1.10 \mathrm{~mm} \times 0.4-0.5$ $\mathrm{mm}$, nearly planspiral (two specimens with a small spire), with 2 1/4 whorls; whorls with deep suture. Aperture large and sub-circular, a little higher than wider. Sculpture with riblets. Shells colorless, transparent.

Remarks: Taylor (1966) mentions that Coahuilix $h u b b s i$ is the only subterranean species in Cuatrociénegas. At Sobaco, C. hubbsi is rare (7 specimens) and associated with Juturnia coahuilae, Assiminea cienegensis, Physa acuta and Ferrissia fragilis.

Material: UJED-MAL-SOB-106-112, 7 specimens.

\section{Coahuilix cf. landyei Hershler, 1985} (Fig. 5j)

Description: According to Hershler (1985) the taxon differs from Coahuilix hubbsi by: 1. Adults have one more whorl and are larger (width, to $1.31 \mathrm{~mm}$ ) than Coahuilix hubbsi; 2 . The last tenth of a whorl is much more inflated than that of Coahuilix hubbsi; 3 . The growth lines of the body whorl are much more pronounced than those of Coahuilix hubbsi; 4. The last third of the body whorl overlaps the preceding whorl; 5 . The aperture is much more inclined to the coiling axis than that of Coahuilix hubbsi; and 6 . The inner lip of the aperture is much less flared than that of Coahuilix hubbsi.

Remarks: The specimens of Coahuilix cf. landyei from Sobaco reach $1.25 \mathrm{~mm}$ in length and are larger in size than C. hubbsi. However, some specimens of $C$. cf. landyei from Sobaco show transitions (in size and morphology) to the previous species, Coahuilix hubbsi, and may be co-specific.

Material: UJED-MAL-SOB-113-117, 5 specimens.

Genus Probythinella Thiele, 1928

\section{Probythinella protera Pilsbry}

(Fig. 5n-p)

Description: Shell medium in size, height $3.2(2.8 \mathrm{~mm}$ second specimen), ovate-conic to pupiform with $4-4.5$ slightly rounded whorls, first whorl near planorbid. Apex blunt. Aperture small, ovate and inclined approximately $30^{\circ}$ away from the coiling axes. Inner lip thickened and adnate to the parietal wall, outer lip strongly thickened.

Remarks: The two shells from Sobaco show 


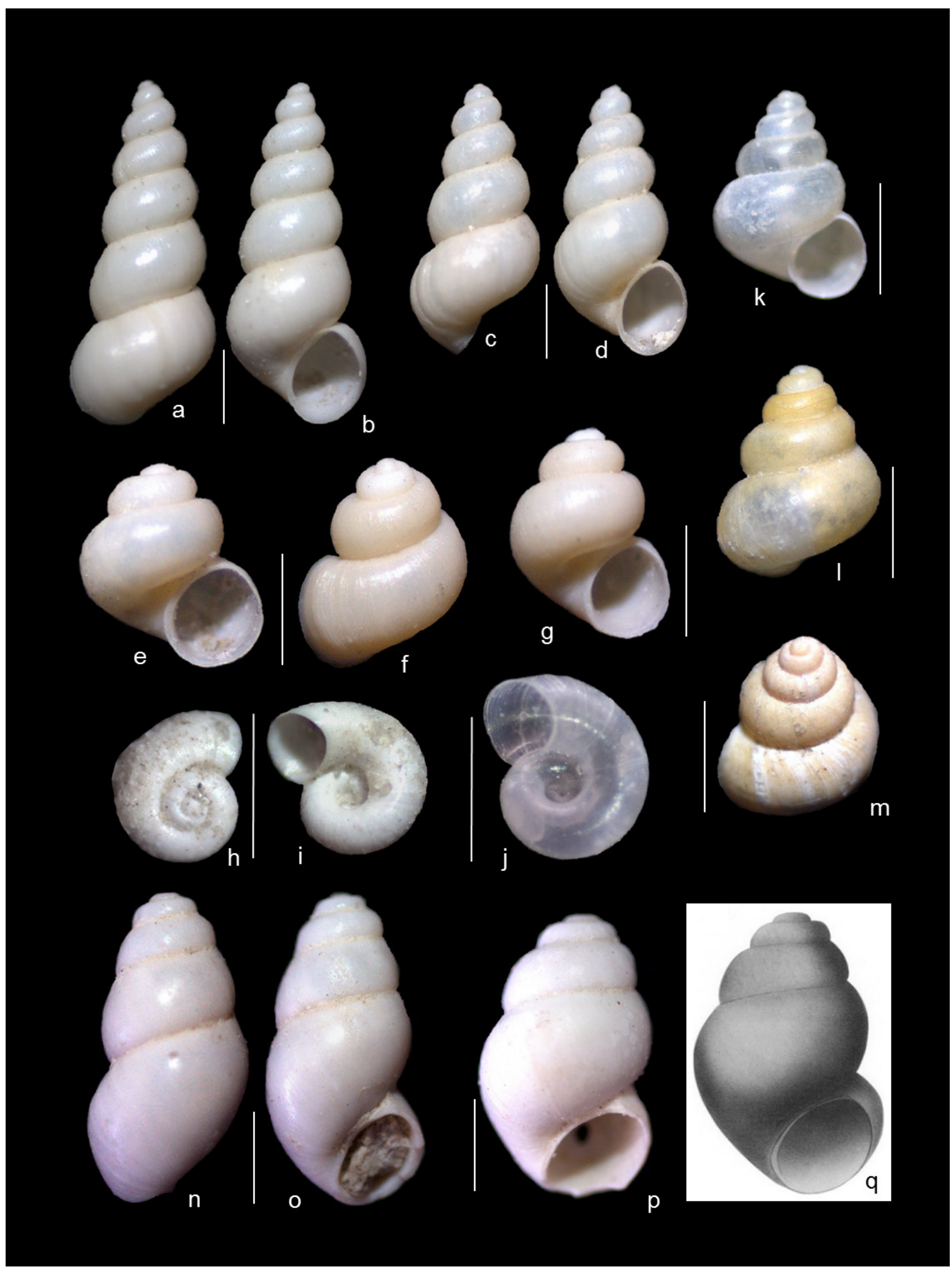

Figure 5. Gastropods of the paleo-poza Caracol, Valley of Sobaco, Coahuila; a-d: Juturnia coahuilae, e-g: Pyrgulopsis manantiali, h-i: Coahuilix hubbsi, j: Coahuilix cf. landyei, k-m: Assiminea cienegensis, n-q: Probythinella protera, q: From Lake Pontchartrain, Louisiana, USA, Morrison, 1965) (bar=1 mm). 
morphological characteristics such as the blunt apex, thickened lips and the general shape that allow its classification into the genus Probythinella Thiele. One of the shells (Fig. 5p) is identical to the material described as Vioscalba louisianae (Fig. 5q) by Morrison (1965) from Lake Pontchartrain, Louisiana, and subsequently included as synonymous with Probythinella protera Pilsbry by Hershler (1996).

The genus Probythinella Thiele includes two taxa, $P$. emarginata Kuster and P. protera Pilsbry, which are distributed along the eastern part of North America. Probythinella protera occurs along the eastern Gulf of Mexico coast in Texas, Louisiana, Mississippi and Alabama and inhabits soft brackish water substrates at $0-2 \mathrm{~m}$ depth. Hershler (1996) reported a sole inland record of the species from Reelfoot Lake, Tennessee, that came from a bird's stomach. This is the first record of the genus Probythinella in Mexico.

Material: UJED-MAL-SOB-118-119, 2 specimens.

Family Assimineidae H. and A. Adams, 1856 Genus Assiminea Fleming, 1828

Assiminea cienegensis (Hershler, Liu and Lang, 2007) (Fig. 5k-m)

Description: Shell broadly conical to long ovate, thin, white colored to transparent, translucent or yellow-amber (periostracum), height: $1.0-1.4$, or even one specimen 1.8 $\mathrm{mm}$. Teleoconch of $2.5-3.5$ moderately convex whorls. Aperture ovate to pyriform, outer lip very thin, columellar lip thicker.

Remarks: The diminutive gastropods from the paleopoza Caracol at Sobaco were identified as Assiminea cienegensis (Hershler, Liu and Lang, 2007), today an endemic species of the Cuatrociénegas Valley. The genus Assiminea Fleming contains five species in North America: A. succinea Pfeiffer and $A$. californica Tryon inhabit brackish coastal habitats on the Atlantic and Pacific sides of the continent; $A$. infima Berry lives in riparian settings in Death-Valley, Nevada; and $A$. pecos Taylor lives in inland aquatic habitats in the Rio Grande Region (Fukuda and Ponder, 2003). Hershler et al. (2007) separated the Mexican population of Assiminea pecos of Cuatrociénegas based on genetic and morphometric differences and described the material as a new species: Assiminea cienegensis. Specimens from Sobaco are similar in shell-structure and size to the recent endemic species from Cuatrociénegas.

Material: UJED-MAL-SOB-120-134, 15 specimens.

Family Physidae Fitzinger, 1833

Genus Physa Draparnaud, 1801

Physa acuta Draparnaud, 1805

(Fig. 6a-c)
Description: Shell elongate-ovate, high spired, with thin but strong walls, smooth with faint spiral growth lines, sinistral, white to yellow, length: $3.5-12.5 \mathrm{~mm}$, width 3.2 $-7.5 \mathrm{~mm}$. Apex pointed. Shell with four to five whorls, the first whorls minute, body whorl very large and globose, suture slightly impressed. Aperture ovate to ear-shaped and very large, about two thirds of the height of the shell, outer lip thin, inner lip broad apprised to the columellar region, columellar fold well marked.

Remarks: Despite several monographs of Physiidae (the last by Taylor, 2003), a new review of the family, especially of the genus Physa, is urgent. The taxonomy of Physa is confusing, with countless synonyms that include more than 40 species and an equal number of subspecies only in the U.S. The molecular phylogenetic investigation of Physiidae carried out by Dillon et al. (2002) and Wethington and Lydeard (2007) suggests the organization of the family into six groups with 13 species. It would be desirable to include also the morphology of the shells to these investigations, especially due to the abundant fossil findings of this genus.

One of the two species from Sobaco is Physa acuta Draparnaud, today a cosmopolitan species but originally native to North America (Dillon et al., 2002). Because of its great morphological variation, this species was described under various synonyms. The material from Sobaco also shows great variability in the shape and size of the shell (Fig. 6a-c).

Physa acuta also occurs in Cuatrociénegas (own observations) and was originally described as Physa virgata Gould by Taylor (1966) at this site. Today, $P$. virgate is accepted as one of the synonyms of Physa acuta (Dillon et al., 2002; Wethington, 2004).

Material: UJED-MAL-SOB-135-157, 23 specimens.

\section{Physa cf. pomilia Conrad, 1834}

(Fig. 6d, e)

Description: Shell similar to $P$. acuta but with the following differences: Shell length: $2.8-6.5 \mathrm{~mm}$ (frequently between $3.5 \mathrm{~mm}$ y $4.5 \mathrm{~mm}$ ), elongate-ovate, apex more rounded (than P. acuta), yellow-brown in color, rarely white, frequently semi-translucent.

Remarks: The second Physa of Sobaco is similar to those of the previous species and the determination of individual specimens is problematic. Large populations facilitate the determination of Physa pomilia Conrad because this species shows a lower rate of variability (plasticity) of length and shape than Physa acuta. The apex is more acute and the shells have a yellow-brown color (Fig. 6d, e). The largest specimen is $6.2 \mathrm{~mm}$ long whereas $P$. acuta reaches $12 \mathrm{~mm}$. Physa pomilia is known from the southeastern United States (Alabama, South Carolina, Connecticut, Florida, California) where the taxon lives on emergent vegetation in ponds, slow pools and backwaters of rivers (Wethington et al., 2009).

Material: UJED-MAL-SOB-158-172, 15 specimens. 


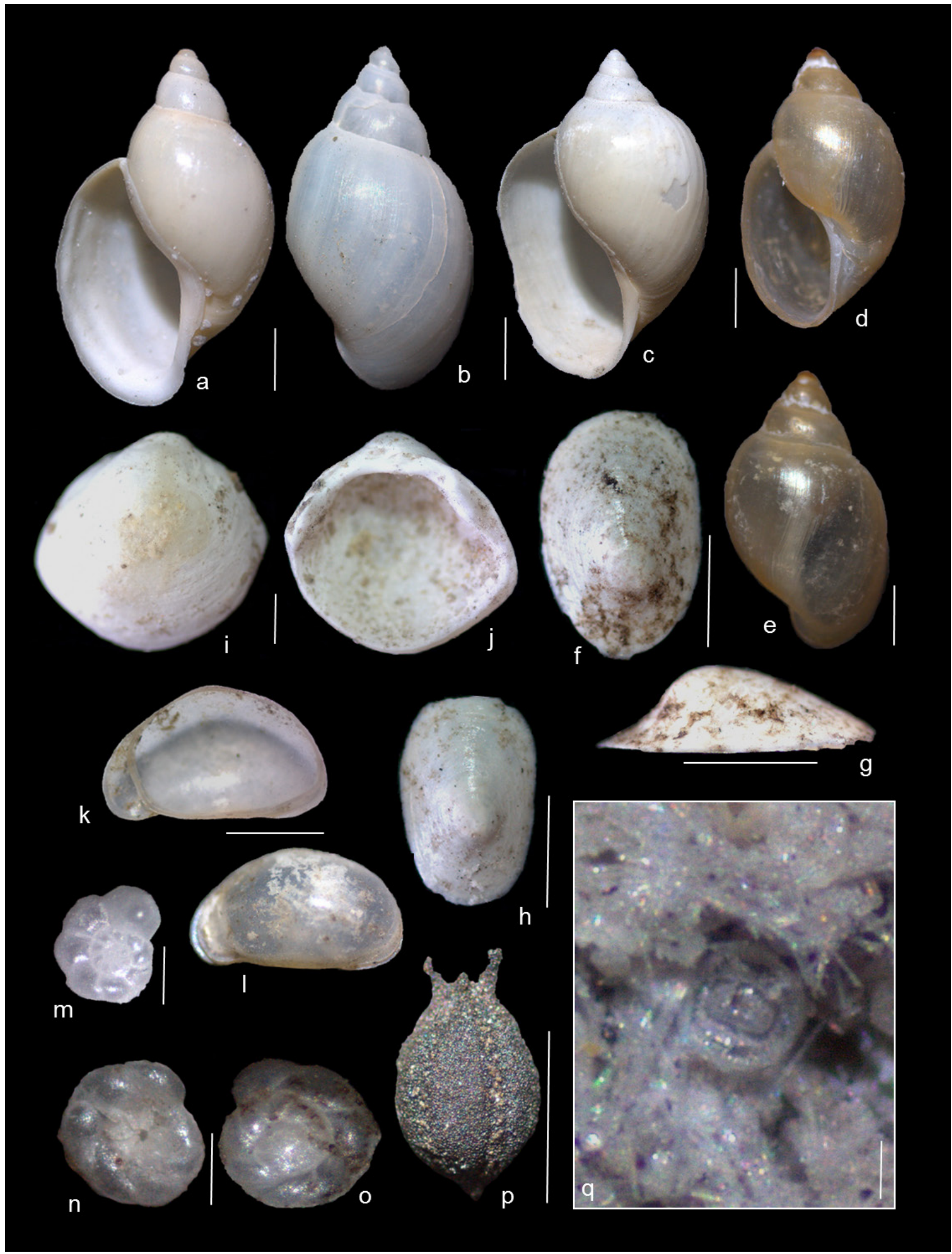

Figure 6. Mollusks, ostracods, foraminifera, diatoms and plants of the paleo-poza Caracol, Valley of Sobaco, Coahuila: a-c: Physa acuta, d, e: Physa pomilia, f-h: Ferrissia fragilis, i, j: Pisidium sp., k, 1: Chlamydotheca arcuata, m-o: Ammonia beccarii, p: Cladium jamaicense, q: Campylodiscus clypeus, (bar $=1 \mathrm{~mm} ; \mathrm{m}, \mathrm{n}, \mathrm{o}, \mathrm{q}$ bar $=0.2 \mathrm{~mm})$ 
Family Planorbidae Rafinesque, 1815

Genus Ferrissia Walker, 1903

Ferrissia fragilis (Tryon, 1863)

(Fig. 6f-g)

Description: Shell oval, white to transparent, moderately elevated, apex acute and turned backwards to the right side slightly behind the center in the posterior section, $2-3 \mathrm{~mm}$ long $(2.1-2.9 \mathrm{~mm})$.

Remarks: Only few specimens of gastropods of the tribe Ancylidae were found in sediments near the paleopoza Caracol. Ferrissia Walker has a near-cosmopolitan distribution in freshwater ecosystems. In the first half of the twentieth century there were more than 20 species of the genus with numerous synonyms and subdivisions of the genus. Basch (1963) reduced the number to five species based on shell morphology, habitat and distribution. The most recent phylogenetic revision of the genus Ferrissia was suggested by Walther et al. (2010). The author emphasizes the great ecophenotipic diversity of the genus and suggests that only two species of Ferrissia, F. fragilis and $F$. rivularis, occur in North America. The shells of Sobaco are very thin and fragile, $2-3 \mathrm{~mm}$ long and have an apex positioned posteriorly and right to the midline. These features correspond with the description of Ferrissia fragilis by Walther et al. (2010). This species populates small ponds and can survive drought conditions (Walther, 2008).

There are also reports of the genus from Cuatrociénegas but there was no specific name assigned nor photographs (Ferrissia sp. in Taylor, 1966). Considering habitat preferences and distribution of the two species of Ferrissia, it is suggested that Ferrissia fragilis also occurs in Cuatrociénegas.

Material: UJED-MAL-SOB-173-179, 7 specimens.

Bivalvia Linnaeus, 1758

Family Sphaeriidae Deshayes, 1855

Genus Pisidium Pfeiffer, 1821

Pisidium sp.

(Fig. 6i, j)

Description: Shell small and heavy; $3.9 \mathrm{~mm}$ high and 3.8 mm wide; quadrangular-rounded, moderately convex; beak prominent, quite far back and broad, shell unornamented, moderately fine striated; periostracum almost completely absent; cardinal teeth almost not visible, eroded.

Remarks: Shape and size of the single left valve coincide with Pisidium Pfeiffer (probably P. compressum). The genus is also present in Cuatrociénegas Valley and was there as Pisidium sp. Taylor (1966) mentioned the occurrence of Pisidium compressum east of Cuatrociénegas in the valley of Río Salado de los Nadadores.

Material: UJED-MAL-SOB-180, 1 specimen.

\section{Discussion and conclusions}

It is noteworthy to mention that the 14 species of gastropods known from Cuatrociénegas are distributed throughout the Valley in more than 200 ponds, creeks and streams, while all seven species at Sobaco were exclusively recorded from a single paleo-lake. The faunal similarities of the mollusk assemblage are clear, and of 10 endemic species of gastropods known from Cuatrociénegas, five were found at Sobaco.

Juturnia coahuilae is the most abundant gastropod at Sobaco. Some of the sediment layers here are composed almost entirely of these small turriform shells. This endemic species occurs in various habitats at Cuatrociénegas, such as playa lakes, pools and marshes, but it is much less common than at Sobaco. Hershler (1984) suggests that the delicate shells of Juturnia coahuilae are easier prey to molluscivorous cichlids than other gastropod species possessing thicker shells and that this species may therefore not be abundant in the Cuatrociénegas pools. So far, there is no evidence of fish remains in the paleo-poza Caracol of Sobaco. The absence of cichlids would then explain the immense density of this species. Hershler et al. (2002) mentions that in Cuatrociénegas, Juturnia coahuilae occurs in small springs often accompanied by Pyrgulopsis manantiali, another endemic species of this valley, where both live in soft sediments and in Chara mats. Our subfossil findings in Sobaco show a quite similar picture, where both gastropods are found in the same layers with at least two species of Chara.

Coahuilix hubbsi, also known from the Cuatrociénegas Valley as a groundwater taxon, was found in the stream (arroyo) in the immediate vicinity of the Paleo-Poza Caracol. There is little information on the ecology of this species. In Cuatrociénegas, Coahuilix hubbsi is often associated with Paludiscala caramba Taylor (1966), another endemic species that has not been confirmed yet at the Sobaco Valley.

Assiminea cienegensis is another endemic species of Cuatrociénegas found at Sobaco. According to Hershler et al. (2007), A. cienegensis lives in "small stands of sedges emerging from slightly elevated mounds in areas where groundwater was very close to the land surface. Collections were made by pulling apart the hard, salt-encrusted exterior of these mats to expose the moist, black-colored bases of vegetation on which the snails live."

Probythinella protera is a coastal-brackish water taxon that was found for the first time outside the coast of the Gulf of Mexico. Its recent ecological requirements coincide well with those of other halophilic species that were found in the Sobaco Valley. Probythinella protera was also identified outside of the coast of the Gulf of Mexico but only in bird stomachs (Hershler, 1996). We suggest that the species was introduced to Sobaco also by avian transport. 
Physa acuta, Physa pomilia and Ferrissia fragilis are other non-endemic species of the Cuatrociénegas Valley that also inhabited the paleo-pozas in Sobaco. Physa acuta is a cosmopolitan freshwater species adapted to a wide range of habitats and therefore less suitable for paleoenvironmental reconstructions. While Bailey et al. (2002) mention a salinity range from freshwater to moderately saline for Physa acuta, Kefford and Nugegoda (2005) emphasize that there is no evidence of a critical salinity threshold for growth and reproduction of this species.

There is little reliable information on the ecology of Physa pomilia, often confused with Physa acuta as they are morphologically very similar. Recent studies of Suski et al. (2012) show that Physa pomilia tolerates increased salinity $\left(4000 \mu \mathrm{S} \mathrm{cm}^{-1}\right)$ but this increase bears (unlike for Physa acuta) no advantage regarding to growth and reproduction. According to Wethington et al. (2009), Physa pomilia inhabits pools in backwaters of rivers draining the coastal plain, typically on vegetation. At Sobaco, the species was found only in the paleo-poza Caracol and was never associated with Physa acuta, which dominates the stream sediments. There is no certainty of the presence of Physa pomilia in Cuatrociénegas. To date we have only observed shells of Physa acuta.

The gastropod assemblage of Sobaco Valley is typical of an extreme environment, in this case for saline and even partially hypersaline conditions, where diversity is low and abundance of individuals is high. The extreme abiotic factors did not allow a great diversity of species. Thus, in the absence of competition, the present taxa had a mass development. A shortage of (submerged) macrophyte vegetation often characterizes these types of extreme environments. At Sobaco, we have only identified remains of algae to date.

The dominance of Juturnia coahuilae indicates that this species is better adapted to this habitat than other gastropods; shells of the taxon are present at almost all horizons at Sobaco. Thorp and Covich (2001) mentioned that the degree of salinity is a controlling factor of the diversity and abundance of species in many recent saline lakes in North America.

Endocarps of Cladium jamaicense Crantz (Sawgrass, Fig. $6 p$ ), are the only remains of the riparian vegetation at Sobaco and support the reconstruction of a saline paleo-environment. In Florida, this species lives in coastal brackish and fresh water marshes and shows adaptation to fire. Wade et al. (1980) reported that Sawgrass “....evolved under a regime of frequent fire, and requires fire to maintain dominance." All endocarps from Sobaco are carbonized and also many carbonized plant remains of the same horizons confirm the repeated occurrence of (paleo-) fires around the water body. Evidences of fires were also reported from a sediment core of a freshwater marsh in the Cuatrociénegas Basin (Eads, 2013).

In addition to mollusks, Ammonia beccarii (Fig. 6m-o), a marine foraminifer, typical of coastal regions of the Gulf of Mexico, appears unexpectedly in the upper part of the profile section (Fig. 4). This species has also been reported in other Pleistocene and Holocene lakes in North America, Africa and Australia, and is considered a good indicator of increased salinities (Cann and DeDeckker, 1981). According to Bradshaw (1957), Ammonia beccarii tolerate salinities of $2 \%$, but is able to reproduce only between $13 \%$ and $40 \%$, reaching highest growth rates at normal salinity of $34 \%$. Their high abundance in the "unit with mass occurrences of foraminifera and diatoms" (Fig. 4) in the upper part of the Sobaco section indicates that this level of salinity was reached in this unit.

Along with Ammonia beccarii, Campylodiscus clypeus (Fig. 6p), a benthic diatom often associated with a brackish, saline environment (Bradbury, 1971, Israde-Alcántara et al., 2002), also occurs in this unit in which the salinity levels were probably similar to sea water. CaballeroMiranda (1997) even classifies Campylodiscus clypeus as a halophilic organism, based on its ecological preference. Chlamydotheca arcuata (Fig. 6, k, 1), an abundant ostracod in Sobaco (and also in Cuatrociénegas) can also be considered as a salinity indicator (Palacios-Fest, 2007). Microorganisms in athalassic saline water are known from numerous other inland lakes and their presence is related to avian transport (Almogi-Labin et al., 1995; Bachhuber and McClellan, 1977, Riedel et al., 2011 and others).

All gastropod species at Sobaco do not show detectable morphological differences to those of Cuatrociénegas which implies that they are conspecific, at least in the paleontological sense. The similarity or identity between Sobaco and Cuatrociénegas species, their little diversification, their endemism, and the lack of Pleistocene precursors imply a recent (Holocene) colonization, probably by avian transport. Communities of Late Pleistocene mollusks, described recently from paleolakes of the same region, contain a different fauna (Czaja et al., 2014).

Our results oppose authors like Taylor (1966), Minckley (1969) and Parodiz (1969) who postulated an ancient (Paleogene) origin of the Cuatrociénegas invertebrate assemblage. Hershler $(1984,1985)$ doubted this early origin of the aquatic ecosystems in the view of small scale endemism and low level intra-basin differentiation. Biological and geological similarities between Cuatrociénegas and Sobaco allow us to conclude that both valleys evolved in a similar way during the Holocene.

\section{Acknowledgements}

The authors would like to thank Dr. Robert Hershler, Smithsonian Institute, Washington, Dr. Amy Wethington, Norfolk and Dr. Robert Dillon Jr., Charleston, for their support in the determination of some gastropods. Special thanks goes to M.C. Christina Ertl, Gómez Palacio, Mexico, Dr. Christian Neumann, Museum für Naturkunde, Leibniz Institute for Evolution and Biodiversity Science, Berlin, 
Germany, and an anonymous reviewer for their assistance in the revision of the text in English.

\section{References}

Almogi-Labin, A., Siman-Tov, R., Rosenfeld, A., Debard, E., 1995, Occurrence and distribution of the foraminifera Ammonia beccarii tepida (Cushman) in water bodies, recent and quaternary, of the Dead Sea Rift, Israel: Marine Micropaleontology, 6, 153-159.

Bachhuber, F.W., McClellan, W.A., 1977, Paleoecology of marine Foraminifera in pluvial Estancia valley, central New Mexico: Quaternary Research, 7, 254-267.

Bailey, P., P. Boon, P., Morris, K., 2002, Australian Biodiversity - Salt Sensitivity Database. Canberra: Land and Water Australia, available at <www.rivers.gov.au/research/contaminants/saltsen.htm $>$.

Basch, P.F., 1963, A review of the recent freshwater limpet snails of North America (Mollusca: Pulmonata): Bulletin of the Museum of Comparative Zoology at Harvard College, 129, 399-461.

Bradbury, J.P., 1971, Paleolimnology of Lake Texcoco, Mexico. Evidence from Diatoms: Limnology and Oceanography, 6 (2), 180-200.

Bradshaw, J.S., 1957, Laboratory studies on the rate of growth of the foraminifer "Streblus beccarii (Linne) var. tepida" Cashman: Journal of Paleontology, 31, 1138-1147.

Caballero-Miranda, M., 1997, Reconstrucción paleolimnológica del Lago de Chalco durante el último máximo glaciar, el registro de diatomeas entre 34000 y 15000 años A.P.: Revista Mexicana de Ciencias Geológicas, 14, 91-100.

Call, R.E., Pilsbry, H.A. 1886, On Pyrgulopsis, a new genus of rissoid mollusk, with description of two new forms: Proceedings of the Davenport Academy of Natural Science, 5, 9-14.

Cann, J.H., DeDeckker, P., 1981, Fossil Quaternaly and living foraminifera from athalassic (non marine) saline lakes, southern Australia: Journal of Paleolontlogy, 55, 660-670.

Cole, G.A. 1984, Crustacea from the Bolson of Cuatro Cienegas, Coahuila, Mexico: Journal of the Arizona-Nevada Academy of Science, 19, 3-12.

Czaja, A., Palacios-Fest, M.R., Estrada-Rodríguez, J.L., Romero Méndez, U., Alba Avila, J.A., 2014, Inland dunes fauna from the Paleolake Irritila in the Comarca Lagunera, Coahuila, Northern Mexico: Boletín de la Sociedad Geológica Mexicana (in press), 66, 3.

Dillon, R.T., Jr., Wethington, A.R., Rhett, J., Smith, T., 2002, Populations of the European freshwater pulmonate Physa acuta are not reproductively isolated from American Physa heterostropha or Physa integra: Invertebrate Biology, 121, 226-234.

Eads, J.H., 2013, Macroscopic Charcoal as Evidence of Long-Term Fire History in the Cuatro Cienegas Valley, Mexico: Master's Theses, University of Tennessee, available at $<\mathrm{http}$ :/trace.tennessee.edu/ cgi/viewcontent.cgi?article $=2621 \&$ context $=u t k$ gradthes $>$

Fukuda, H., Ponder, W.F., 2003, Australian freshwater assimineids, with a synopsis of the recent genus group taxa of the Assimineidae (Mollusca: Caenogastropoda: Rissooidea): Journal of Natural History, 37, 1977-2032.

Hershler, R., 1984, The hydrobiid snails (Gastropoda: Rissoacea) of the Cuatro Cienegas Basin: Systematic relationships and ecology of a unique fauna: Journal of the Arizona-Nevada Academy of Science, 19 (1), 61-76

Hershler, R., 1985, Systematic revision of the Hydrobiidae (Gastropoda: Rissoacea) of the Cuatro Cienegas Basin, Coahuila, Mexico: Malacologia, 26, 31-123.

Hershler, R., 1994, A review of the North American freshwater snail genus Pyrgulopsis (Hydrobiidae): Smithsonian Contributions to Zoology, 554, 1-115.

Hershler, R., 1996, Review of the North American aquatic snail genus Probythinella (Rissooidea: Hydrobiidae): Invertebrate Biology 115 (2), 120-144

Hershler, R., Liu, H.-P., Stockwell, C.A., 2002, A new genus and species of aquatic gastropods (Rissooidea: Hydrobiidae) from the North
American Southwest: phylogenetic relationships and biogeography: Proceedings of the Biological Society of Washington, 115 (1), $171-188$.

Hershler, R., Liu, H.-P., Lang, B.K., 2007, Genetic and morphologic variation of the Pecos assiminea, an endangered mollusk of the Rio Grande region, United States and Mexico (Caenogastropoda: Rissooidea: Assimineidae): Hydrobiologia, 579 (1), 317-335.

Hershler, R., Liu, H.-P., 2009, New Species and Records of Pyrgulopsis (Gastropoda: Hydrobiidae) from the Snake River Basin, Southeastern Oregon: Further Delineation of a Highly Imperiled Fauna: Freshwater Biology, 54(6), 1285-1299.

Israde-Alcántara, I., Garduño-Monroy, V.H., Ortega-Murillo, R., 2002, Paleoambiente lacustre del Cuaternario tardío en el centro del lago de Cuitzeo: Hidrobiologica, 2, 61-78.

Kefford, B.J. and Nugegoda, D., 2005, No evidence for a critical salinity threshold for growth and reproduction in the freshwater snail Physa acuta: Environmental Pollution, 134, 377-383.

Minckley, W.L., 1969, Environments of the Bolsón of Cuatro Ciénegas, Coahuila, México: Science Series, University of Texas, El Paso, Texas, 2, 1-65.

Morrison, J.P.E., 1965, New brackish water mollusks from Louisiana: Proceedings of the Biological Society of Washington, 78, 217-224.

Palacios-Fest, M.R., 2007, Superfamily Cypridoidea: Common ostracodes in the American Southwest. Produced at California State UniversityBakersfield, available at $<$ http://www.docstoc.com/docs/117353499/ Class-Ostracoda-Subclass-Po-opa-Order-Po-opida-Suborder $>$.

Parodiz, J.J., 1969, The Tertiary non-marine Mollusca of South America: Annals of the Carnegie Museum, 40, 1-242.

Riedel, F., Kossler, A., Tarasov, P., Wünnemann, B., 2011, A study on Holocene foraminifera from the Aral Sea and West Siberian lakes and its implication for migration pathways: Quaternary International, 229, 105-111.

Servicio Geológico Mexicano (SGM), 2003, Informe de La Carta Geológico-Minera, Sierra de las Delicias G13-B87, Escala 1:50000: Coahuila, Consejo de Recursos Minerales, Secretaria de Economía.

Suski, J.G, Salice, C.J., Patiño, R., 2012, Species-specific and transgenerational responses to increasing salinity in sympatric freshwater gastropods: Environmental Toxicology and Chemistry, 31(11), 2517-2524

Taylor, D.W., 1966, A remarkable snail fauna from Coahuila, Mexico: The Veliger, 9, 152-228.

Taylor, D.W., 2003, Introduction to Physidae (Gastropoda: Hygrophila) biogeography, classification, morphology: Revista de Biología Tropical, 51 (1), 1-287.

Thiele, J., 1928, Revisions des Systems der Hydrobiiden und Melaniiden: Zoologische Jahrbücher Abteilung für Systematik Ökologie und Geographie der Tiere, 55, 351-402.

Thorp, J.H., Covich, A.P., 2001, Ecology and Classification of North American Freshwater Invertebrates: San Diego, Academic Press, $1056 \mathrm{p}$.

Wade, D., Ewel, J., Hofstetter, R., 1980, Fire in South Florida ecosystems: General Technical Reports SE-17. Asheville, NC: U.S., Department of Agriculture, Forest Service, Southeastern Forest Experiment Station, $125 \mathrm{p}$

Walther, A.C., 2008, A systematic study of North American freshwater limpets (Gastropoda: Hygrophila: Ancylidae): U.S.A., University of Michigan, Ph.D. Thesis, $122 \mathrm{p}$.

Walther, A.C., Burch, J.B., Foighil, D.O., 2010, Molecular phylogenetic revision of the freshwater limpet genus Ferrissia (Planorbidae: Ancylinae) in North America Yields two species: Ferrissia (Ferrissia) rivularis and Ferrissia (Kincaidilla) fragilis: Malacologica, 53, 2545 .

Wethington, A.R., 2004, Phylogeny, taxonomy, and evolution of reproductive isolation in Physa (Pulmonata: Physidae): U.S.A, University of Alabama, Tuscaloosa, Ph.D. Dissertation, $119 \mathrm{p}$.

Wethington, A.R., Wise, J.,Dillon, R.T. Jr., 2009, Genetic and morphological characterization of the Physidae of South Carolina, with description of a new species: Nautilus, 123, 282-292. 
Wethington, A.R., Lydeard, C., 2007, A molecular phylogeny of Physidae (Gastropoda: Basommatophora) based on mitochondrial DNA sequences: Journal of Molluscan Studies, 73, 241-257.
Manuscript received: May 18, 2014.

Corrected manuscript received: August 7, 2014.

Manuscript accepted: August 12, 2014. 